Waldemar Rozynkowski*

Toruń

\title{
O domu rodzinnym bl. ks. Stefana Wincentego Frelichowskiego
}

\section{Wstęp}

Pierwszym środowiskiem wychowawczym ks. Stefana Wincentego Frelichowskiego była oczywiście rodzina. Już na wstępie możemy zaznaczyć, że doświadczał jej przez całe swoje życie, tzn. jako dziecko, dorastający młodzieniec, seminarzysta, ksiądz i wreszcie więzień. Do jesieni 1931 roku, czyli przez przeszło 18 lat, mieszkał wraz z rodziną w Chełmży. Od wstapienia do seminarium duchownego w Pelplinie jego związki z najbliższymi nabrały innego charakteru, nigdy jednak nie uległy zerwaniu. Najmniej intensywny okres w tych relacjach to był prawdopodobnie czas bezpośrednio po jego święceniach, czyli czas posługiwania przy biskupie oraz kilkumiesięczna praca w Wejherowie na początku 1938 roku.

Późniejszy Błogosławiony wielokrotnie był obdarzany miłością ze strony najbliższych. Nie mamy wątpliwości, że prawdziwe i szczere były słowa, które zapisał w Pamiętniku pod datą 23 stycznia 1934 roku (był wtedy na III roku seminarium): „Jak to miło jest mieć kochanych swoich”1. Wspominał wtedy swój pobyt w domu w okresie świąt Bożego Narodzenia w grudniu 1933 roku.

Trudno w krótkim artykule dokonać całościowej charakterystyki podjętego tematu. Dotykamy przecież osoby o bogatym doświadczeniu życiowym, w które zostało

* Dr historii, mgr teologii, adiunkt w Instytucie Historii i Archiwistyki UMK w Toruniu.

${ }^{1}$ Błogosławiony ks. Stefan Wincenty Frelichowski, Pamiętnik, Toruń 2003, s. 85 (dalej: Pamiętnik). 
wpisane bardzo wyraźnie doświadczenie rodziny². Będzie to oczywiście charakterystyka wybiórcza, jednocześnie mamy nadzieję, że otwierająca dalsze szczegółowe badania w tym zakresie.

Chciałbym, abyśmy w tym krótkim opisie nie stracili z oczu podstawowego faktu, który, moim zdaniem, naznaczył atmosferę domu rodzinnego Błogosławionego, mianowicie, że żył on w rodzinie wielodzietnej.

\section{O rodzinie}

Rodzicami ks. Stefana byli Marta Frelichowska z domu Olszewska (1886-1965) i Ludwik Frelichowski (1883-1957). Pobrali się w 1908 roku. Mieli sześcioro dzieci, czyli Stefan miał dwóch braci: Czesława (ur. 1909) i Leonarda Wiktora (najczęściej zwanego Leszkiem) - ur. w 1911 roku, oraz trzy siostry: Eleonorę - ur. w 1916 roku, Stefanię - ur. w 1919 roku, oraz Marcjannę Martę - ur. w 1926 roku. Błogosławiony urodził się w 1913 roku, tzn. był młodszy od swoich braci - cztery lata od Czesława i dwa lata od Leszka, starszy jednak od sióstr, od najmłodszej o 13 lat.

Wzrastał z rodzeństwem i uczestniczył w tworzeniu wspólnego życia. Przywołajmy w tym miejscu kilka obrazów i zestawień, które je opiszą. Doświadczył obecności starszych braci, szczególnie Czesława. Był zapewne z niego dumny, jak i cała rodzina, kiedy jesienią 1929 roku rozpoczął on studia prawnicze w Poznaniu. Bardzo głęboko przeżył jego śmierć, miał wtedy 17 lat. Kiedy 14 III 1936 roku przyjmował święcenia kapłańskie w katedrze pelplińskiej, jego najmłodsza siostra Marcjanna przystępowała akurat do I Komunii św. Kiedy w 1938 roku obejmował wikariat w Toruniu jego starszy brat już od kilku lat prowadził rodzinny interes piekarski w Chełmży, siostra Stefania uczęszczała do liceum, natomiast najmłodsza Marcjanna kończyła właśnie szkołę podstawową.

Pani Marta najstarszego syna urodziła, kiedy miała 23 lata, natomiast najmłodszą córkę w wieku 40 lat. Pan Ludwik miał odpowiednio 26 i 43 lata. Jak widać, rodzina powiększała się na przestrzeni 17 lat. Przez ten cały czas wnosiła ona ten niesamowity dynamizm życia, który staje się udziałem tych wszystkich, którzy współuczestniczą w pojawianiu się nowego życia. Może on być porównywalny tylko z tajemnicą odejścia - śmiercią.

Wydaje się, że samo przywołanie powyższych zestawień prezentuje nam już rodzinę Błogosławionego. Na pewno dotykamy w niej rzeczywistości bardzo dynamicznej, w dużej mierze związanej właśnie z faktem wielodzietności.

Atmosfera wielodzietności wypływała nie tylko z najbliższej rodziny, pokolenia, w którym sam żył, ale to było pewne dziedzictwo, które przekazywała jego rodzi-

${ }^{2} \mathrm{~W}$ dotychczasowych badaniach najwięcej miejsca rodzinie Frelichowskich poświęcił R. Zadura, Dom rodzinny bt. ks. Stefana Wincentego Frelichowskiego, Biuletyn Parafii Wniebowzięcia Najświętszej Marii Panny i Błogosławionego Księdza Stefana Wincentego Frelichowskiego w Toruniu, nr 9 (Błogosławiony Ksiądz Stefan Wincenty Frelichowski, Materiały, nr 9), Toruń 2005, s. $31-44$. 
na, była to jakaś cecha tej wspólnoty rodzinnej ${ }^{3}$. Dziadek Jakub Frelichowski, który ożenił się z Franciszką z domu Łuczyk, miał ośmioro dzieci. Oni z kolei zakładając własne rodziny posiadali kolejno: Jakub - 9 dzieci, Franciszka - 13, Andrzej - 4, Marianna-3, Bronisława - (?), Tekla - 1, Ludwik (ojciec Stefana) - 6 .

Ze strony rodziny Olszewskich wyglądało to następująco: Wawrzyniec Olszewski, który poślubił w 1791 roku Jadwigę Maćkiewiczówną - 8 dzieci; Paweł, który dnia 25 lutego 1818 roku poślubił on Mariannę Murawską - 11; Jakub, który ożenił się w 1856 roku z Agnieszką Zielińską - 7. Jego najstarszy syn Stanisław, z zawodu szewc, poślubił Wiktorię z domu Nawrocką, z którą miał trójkę dzieci (w tym matkę Stefana Martę). Po śmierci męża w 1891 roku, Wiktoria wyszła w 1892 roku ponownie za mąż za Stanisława Konkowskiego, z którym miała cztery córki. Tak więc zarówno od strony mamy, jak i taty, Stefan posiadał znaczną rodzinę.

\section{Aktywność zawodowa i społeczna}

Atmosferę rodziny tworzyła aktywność zawodowa i społeczna najbliższego otoczenia. Stefan w swoim pamiętniku zapisał, iż dziadek Olszewski był szewcem z powołania, nazwał go wręcz artystą buty, które wykonywał: „,były tak dobre, że nie można było zrobić lepszych"4.

Podobnie szewcem był dziadek Stanisław Konkowski. Prowadził w Chełmży sklep oraz warsztat szewski przy ulicy Toruńskiej. Był członkiem Bractwa Szewskiego gromadzącego się przy ołtarzu Matki Bożej Bolesnej. Ponadto należał do Bractwa Kurkowego i Stowarzyszenia Kupców Katolickich w Chełmży.

Dzieci Ludwika i Marty Frelichowskich często odwiedzały swoich dziadków w Chełmży, gdzie zawsze mogły liczyć na ich otwartość i opiekuńczość 5 . Pani Marcjanna wspominała: „Ilekroć mieliśmy czas przed południem szliśmy do dziadków”6.

Pan Ludwik z zawodu był mistrzem piekarskim. Należał do Komisji Kwalifikacyjnej Cechu Piekarsko-Cukierniczego. Wspólnie z żoną spotykali się i formowali w Bractwie Różańcowym. Pełnił również funkcję skarbnika w Stowarzyszeniu Kupców Katolickich. Stefan Wincenty podziwiał go, gdyż był dla niego uosobieniem pracowitości i szlachetności ${ }^{7}$.

Pani Marta Frelichowska była osobą bardzo energiczną, jak wspominała jej córka Marcjanna Jaczkowska, to właśnie ona trzymała cały dom w ryzach. W młodości

${ }^{3}$ Informacje o najbliższej rodzinie odtworzył R. Zadura, $W$ poszukiwaniu korzeni-o rodzinie bt. ks. Stefana Wincentego Frelichowskiego, Biuletyn Parafii Wniebowzięcia Najświętszej Marii Panny i Błogosławionego Księdza Stefana Wincentego Frelichowskiego w Toruniu, nr 9 (Błogosławiony Ksiądz Stefan Wincenty Frelichowski, Materiały, nr 9), Toruń 2005, s. 24-29.

${ }^{4}$ Pamiętnik, s. 91.

${ }^{5}$ R. Zadura, Dom rodzinny, s. 33-34.

${ }^{6}$ W. Rozynkowski, Rozmowa z paniq Marcjannq Jaczkowskq, siostra bt. ks. Stefana Frelichowskiego - cz. I, Pustynia w mieście, Torun, nr 11/1 (12) z 2002/2003, s. 3.

${ }^{7}$ R. Zadura, Dom rodzinny, s. 34-35. 
często angażowała się w życie kulturalne Chełmży, śpiewając w Polskim Towarzystwie Śpiewaczym i w chórze kościelnym. Była członkinią Bractwa Różańcowego ${ }^{8}$.

Krystyna Podlaszewska, przyjaciel rodziny Frelichowskich i autorka monografii poświęconej ks. Stefanowi, w swoich wspomnieniach tak scharakteryzowała panią Martę: „Czuło się jej głęboką wiarę, ogromne zaufanie Bogu, a przy tym pokój wewnętrzny, mimo wszystkich doświadczeń życiowych"9.

Ważne w tej charakterystyce może być także przypomnienie jeszcze jednego faktu. Najbliższa rodzina Stefana utrzymywała się, prowadząc własną działalność gospodarczą: dziadek Jakub Frelichowski był rolnikiem; dziadek Stanisław Olszewski (podobnie Stanisław Konkowski) był szewcem; ojciec Błogosławionego prowadził interes piekarski. Stefan oddychał atmosferą ojcowizny i warsztatu domowego, który dawał utrzymanie. Być może dzięki temu doświadczeniu mógł zapisać w pamiętniku (był na pierwszym roku w seminarium), że dziękuje rodzicom za: ,poszanowanie dla pracy"10 oraz za „zamiłowanie do rzeczy dobrej, solidnej”"11.

\section{Dom rodzinny}

Przez pierwsze trzy lata po ślubie rodzina Frelichiwskich mieszkała w Bydgoszczy przy ul. Grunwaldzkiej 5. Tam przyszli na świat starsi bracia Stefana: Czesław i Leszek. Od jesieni 1911 roku Frelichowscy zamieszkali w Chełmży przy ul. Chełmińskiej 31. Po zmianie numerów domów na początku lat trzydziestych, dom otrzymał numer 5. Zacytujmy w tym miejscu opis domu, którego dokonał R. Zadura:

Przez dużą bramę można było wejść na podwórze, na którym po prawej stronie znajdowała się piekarnia. W niej stał piętrowy piec węglowy, który miał dwa wejścia do wypieków. Po lewej stronie mieściły się schody, które prowadziły na strych, gdzie znajdował się magazyn do mąki. Pod schodami w rogu głównego pieca umieszczony był magazyn $\mathrm{z}$ węglem. Po prawej stronie stały dwie ręczne maszyny do wyrobu chlebowego ciasta (tzw.: bojty). Za nimi umieszczona była maszyna do wytłaczania bułek. Tuż obok znajdowało się małe okienko, które łączyło piekarnię z mieszkaniem. Po lewej stronie ustawione były regały do pieczywa. Z protokółu sporządzonego podczas kontroli piekarni w 1928 r. dowiadujemy się, m.in. o sposobie ręcznej produkcji w piekarni Frelichowskich. Zużycie opału wynosiło od 75-100 kg węgla [dziennie]. Personel składał się z jednego czeladnika i dwóch uczniów. Wypiekano [dziennie] $160 \mathrm{~kg}$ chleba żytniego, 75 $\mathrm{kg}$ bułek i $5 \mathrm{~kg}$ ciasta. Jeden kilogram chleba pszennego kosztował złotówkę, natomiast chleba żytniego 50 groszy.

${ }^{8}$ Tamże, s. 35 .

${ }^{9}$ L. Maryks, Matka kapłana, Głos z Torunia dodatek do tygodnika katolickiego „Niedziela”, nr 21 z 23 maja 1999, s. I.

${ }^{10}$ Pamiętnik, s. 48.

${ }^{11}$ Tamże, s. 90. 
Sklep znajdował się na parterze tuż obok wjazdu na podwórze. W mieszkaniu na parterze mieściły się dwa pokoje, kuchnia, duża jadalnia oraz salonik. Na piętrze było pięć pokoi, od ulicy Chełmińskiej dwa duże i jeden mniejszy, gdzie swoją sypialnię mieli rodzice. Chłopcy mieszkali w dużym pokoju od strony podwórza. W jego pobliżu mieściły się schody prowadzące na strych. Tam w małym pokoiku mieszkała „babunia”, którą była pani Marjanna Dormowicz, obca osoba, przygarnięta przez państwo Frelichowskich. Pomagała ona przy różnych pracach domowych ${ }^{12}$.

Siostra Marcjanna tak wspominała dom rodzinny:

W nim tętniło życie wieczorami. Zawsze przychodzili do nas dziadkowie i ciocia. Wszystkie uroczystości rodzinne odbywały się także u nas, ponieważ nasz dom był stosunkowo duży. Jego próg przekraczało też wiele młodych osób. Często śpiewaliśmy pieśni narodowe, patriotyczne i młodzieżowe. Oczywiście, były także kłopoty i zmartwienia. Czasami mieliśmy trudności finansowe. Ale wydaje mi się, że ten nasz dom był bardzo spójny. Nie pamiętam oczywiście wszystkich sytuacji. W pamięci pozostanie mi wspomnienie październikowych kolacji, które zawsze kończyły się modlitwą na różańcu, mimo że na różaniec chodziliśmy do kościoła. Często modlitwę tę odmawiali razem z nami czeladnicy, którzy uczyli się zawodu u taty ${ }^{13}$.

\section{Doświadczenia momentów trudnych - wymagających}

Błogosławiony doświadczył w rodzinie nie tylko chwil pełnych radości, ale także momentów trudnych, wymagających od niego dużego zaangażowania, aby im sprostać. To zapewne one miały także ogromny wpływ na kształtowanie postawy przyszłego kapłana. Być może największe piętno naznaczyła śmierć najstarszego brata Czesława, przypomnijmy, że Stefan miał wtedy 17 lat. Chorobie i umieraniu brata poświęci spory zapis w pamiętniku. Napisał między innymi tak:

Gdy przyszedłem do szpitala to Czesiu mój kochany brat, rozstawał się z tym światem, o wpół do piątej po południu 4 marca 1930. Straciłem brata, a rodzice swego syna, swoją dumę tu na ziemi. Straciłem brata. Był on mi rzeczywiście starszym ukochanym bratem $^{14}$.

Przechodząc od tego wydarzenia prawie dwadzieścia lat później, warto w tym miejscu przywołać także to, co wydarzyło się od jesieni 1939 roku, tzn. czas więzie-

${ }^{12}$ R. Zadura, Blogostawiony ks. Stefan Wincenty Frelichowski (1913-1945), Toruń 2004, s. 21-22 [maszynopis pracy magisterskiej przechowywany w Archiwum UMK w Toruniu].

${ }^{13}$ W. Rozynkowski, Radosnym Panie! O bt. ks. Stefanie Wincentym Frelichowskim, Torun 2004, s. $12-14$.

${ }^{14}$ Pamiętnik, s. 28. 
nia i obozów. W tych nieludzkich warunkach przeżył przeszło pięć lat. W naszych rozważaniach ważnym jest przede wszystkim to, że ten czas naznaczony był niezwykle intensywnie domem rodzinnym. To oczywiście swoisty owoc dotychczasowych relacji, owoc doświadczanej przez wiele lat atmosfery rodzinnej. Tę część życia Błogosławionego poznajemy dzięki zachowanej korespondencji obozowej ${ }^{15}$.

To nie przypadek, że w korespondencji najwięcej miejsca poświęca właśnie rodzinie. W zachowanych listach porusza najróżniejsze sprawy, czasami nawet z racji specyfiki sytuacji trudne do zrozumienia. W konsekwencji to jego najbliższa rodzina uczestniczyła najpełniej w jego doświadczeniach. Oni wspólnie przez przeszło pięć lat wzrastali w tym trudnym klimacie, który zaprowadził ks. Stefana do godności Błogosławionego ${ }^{16}$.

Przytoczmy fragment listu, który skierował do siostry Maryli, napisany dnia 11 I 1944 roku. Napisał go z okazji 18 urodzin siostry:

Masz swoje 18 lat Marylu, wiesz, co życie znaczy. Ja, moja droga siostro, życzę Ci byś ukochała kogoś Tobie odpowiedniego, by to był człowiek dobry i szlachetny i pracowity. O taką miłość dobrą modlę się dla Ciebie. Jeżeli jej nie masz to módl się też. I czekaj, nie spiesz się. Może będziesz kiedyś i matką i żoną. Chciałbym byś dzieciom kiedyś mogła nieskalany pocałunek na głowie złożyć i niezbrukanymi pogładzić ich włoski rękami. By dzieci twe dobrą matkę miały, byś dar wychowania ich miała, proś Boga o młodość i miłość dobrą i Bożą, aby nic takiego nie było czego byś się przed ludźmi i dziećmi twymi wstydzić miała ${ }^{17}$. [U dołu listu dopisze jeszcze:] a gdy kto bezczelnie do Ciebie przyjdzie to trzaśnij go $\mathrm{w}$ twarz ${ }^{18}$.

Wypowiedziane wyżej życzenia, to swoisty program wychowawczy, którego w dużym stopniu sam doświadczył w swojej najbliższej rodzinie.

\section{O rodzicach}

Echem lektury Ewangelii według św. Łukasza, fragmentu o domu Elżbiety i Zachariasza, domu kapłańskim, były wspomnienia własnego domu rodzinnego. Napisał między innymi tak:

${ }^{15}$ Błogostawiony ks. Stefan Wincenty Frelichowski. Listy obozowe, oprac. M. Nędzewicz, Toruń 2005, ss. 250. Zob. także: W. Rozynkowski, Korespondencja obozowa bt. ks. Stefana Wincentego Frelichowskiego, Biuletyn Parafii Wniebowzięcia Najświętszej Marii Panny i Błogosławionego Księdza Stefana Wincentego Frelichowskiego w Toruniu, nr 7 (Błogosławiony Ksiądz Stefan Wincenty Frelichowski, Materiały, nr 7), Toruń 2003, s. 21-27.

${ }^{16}$ Listy obozowe oczekują na szczegółową analizę.

${ }^{17}$ Błogostawiony ks. Stefan Wincenty Frelichowski. Listy obozowe, s. 162-163.

${ }_{18}$ Tamże, s. 163. 
Boże, dziękuję Ci z całego serca za moich rodziców chrześcijańskich. Dziękuję Ci za Matkę, która mnie zawsze do Ciebie prowadziła i w duszę pierwsze ziarna miłości dla Ciebie wsiała. Dziękuję Ci Boże, za mego ojca tak czynnego, we wszystkim zaradnego, pracującego aż do stargania swych sił. Dającego nam wzór miłości dla bliźnich, dla dzieci, dla życia. Dziękuję Ci Boże, bo nie umiem ich przymiotów wyrazić, ale głęboko tkwią mi w duszy. a dom rodzinny, błogi ten dom ileż dał radości i ukochania Ciebie, o Boże. Te modlitwy wspólne, te różańce, litanie w Wielkim Poście itd. Boże mój, dziękuję Ci ${ }^{19}$.

Opis ten oddaje ciepłą i pełną miłości atmosferę domu, w którym wzrastał Stefan.

W Pamiętniku kilkakrotnie wspomina ojca. Dużo pisze o nim w związku ze śmiercią swojego brata (1930 rok). Dowiadujemy się, że był on także chory. Już po śmierci brata tak zauważył jego osobę:

Straciłem brata a rodzice swego syna, swoją dumę tu na ziemi. Najwięcej troski sprawiał teraz chory tatuś. Całe szczęście, że wtenczas wstał i poszedł do szpitala. Bo gdyby on nie był przy śmierci Czesia, to z pewnością skutki by były straszne. Dzisiaj jeszcze oczekuję pogorszenia ${ }^{20}$.

Inny fragment, w którym przywołał osobę ojca napisał w związku ze swoimi dwudziestymi pierwszymi urodzinami:

Na dzień mego pełnolecia napisał mi też powinszowanie tatuś. Kilka słów od ojca. Zawsze tylko mamusia pisze, a tu tatuś kilka słów. To mnie tak bardzo ucieszyło. Najwięcej ze wszystkich pozdrowień. List ten rodziców moich był taki ładny, głęboki i wzruszający, że wlepię go do tego pamiętnika ${ }^{21}$.

Przyszły Błogosławiony posiadł w swoim życiu doświadczenie ojca. Wiedział i odczuwał, że ojciec zajmuje w niej szczególne miejsce. Z trwogą mógł tylko przeczuwać, co może oznaczać jego brak.

Mama podarowała Stefanowi pamiętnik, który jest dla nas dzisiaj jednym z podstawowych źródeł poznania jego sylwetki duchowej oraz jego otoczenia, w tym także rodziny. To mama zapisała w nim pierwszą stronę. Słowa te z perspektywy lat stają się nie tylko życzeniami, ale swoistym programem życiowym, który wypełnił się w życiu ks. Stefana:

Prowadź się przez życie Twoje

czy to przy pracy

${ }_{19}$ Błogostawiony ks. Stefan Wincenty Frelichowski. Rozważania na tle Ewangelii, oprac. W. Rozynkowski, s. maszynopisu 5-6 [w druku].

${ }^{20}$ Pamiętnik, s. 28.

${ }^{21}$ Tamże, s. 95. 
czy w rozrywkach

tak - abyś się Bogu podobał.

Tych parę, lecz dla Ciebie

tak dobrze myślących słów

wpisała $\mathrm{Ci}$

Twoja kochająca

Matka.

Chełmża, 4 kwietnia 1930 r.

w naszej willi ${ }^{22}$.

\section{Zakończenie}

Kilka miesięcy po przekroczeniu progu seminarium w liście do kuzynki Stanisławy Olszewskiej napisał: „Ciężko mi było opuścić dom”23. W Pamiętniku pod datą 21 kwietnia 1932 roku (I rok seminarium) zapisał:

rodzina moja dała mi zdrowy i jasny pogląd na życie. Wszczepiła w mą duszę ten boski pierwiastek, wszczepiła mi miłość ogólnoludzką dla uciśnionych i biednych i dała mi poszanowanie dla pracy ${ }^{24}$.

Wzrastanie w takim klimacie spowodowało, że kiedy dwa lata wcześniej otrzymał propozycję zostania drużynowym napisał: ,a pchać drużynę, aby wegetowała nie chcę"25.

Pozytywne doświadczenie rodziny pozwoliło mu dorosnąć do postawienia jak najbardziej naturalnych w życiu młodego człowieka, pytań o przyszły zawód oraz o własną rodzinę. Napisze między innymi:

czy może w innym zawodzie byłbym pożyteczniejszy, czy mógłbym lepiej wypełniać słowa Chrystusa i będąc mężem rodziny, żyjąc w społeczeństwie, być kapłanem świeckim, wypełnić swe życie według poleceń Akcji Katolickiej i wprowadzić w czyn cel Sodalicji: przez uświęcenie siebie samego uświęcić stany i przez stany społeczeństwo ${ }^{26}$.

Dzięki rodzinie zbudował w sobie odpowiedzialność i solidność. Być może właśnie te zalety zaprowadziły go do harcerstwa, a na pewno pozwoliły mu w tym właśnie środowisku rozwinąć się, a jednocześnie realizować z powodzeniem ideały harcerskie, urzeczywistniać je i przynosić dojrzałe owoce. Przecież harcerstwo nie

\footnotetext{
22 Tamże, s. 18-19.

${ }^{23}$ Kopia listu w posiadaniu autora.

${ }^{24}$ Pamiętnik, s. 48.

25 Tamże, s. 23.

26 Tamże, s. 32.
} 
było i nie jest jakimś zakładem resocjalizacyjnym, nawet jeżeli spełnia czasami i takie funkcje. Ono chce bazować na zdrowych fundamentach wychowania rodzinnego i pełnić wobec rodziny jedynie funkcję pomocniczą ${ }^{27}$. Wydaje się, że te właśnie założenia spełniły się w życiu ks. Stefana. I chociażby z tego tylko powodu, a może przede wszystkim, warto przypominać jego postać w środowisku skautów.

Trudno zrozumieć postać bł. ks. Stefana Wincentego Frelichowskiego bez jego rodziny. Jego postać staje się dla nas rozpoznawalna właśnie poprzez rodzinę. Dodajmy, że i wielu poznało późniejszego Błogosławionego dzięki rodzinie, szczególnie dzięki najmłodszej siostrze Marcjannie.

Na koniec zwróćmy uwagę na jeden ciekawy aspekt. Głębokie doświadczenie rodziny, jakie bije od postaci ks. Stefana przekłada się na następujący fakt: w prośbach i podziękowaniach kierowanych za przyczyną Błogosławionego spotykamy wiele takich, które dotyczą rodziny, być może jest ich nawet najwięcej. Dotykają one różnych spraw, jednak ich swoistą osią jest pojawiające się słowo „rodzina”28.

\section{Über das Familienhaus des sel. P. Stefan Wincenty Frelichowski (Zusammenfassung)}

Es wäre schwer, die Gestalt des seligen P. Stefan Wincenty Frelichowski zu verstehen, ohne seine Familie kennen zu lernen. Seine Persönlichkeit wird für uns erkennbar gerade durch die Familie. Es soll auch hinzugefügt werden, dass viele den späteren Seligen durch seine Familie kennen gelernt haben, insbesondere durch seine jüngste Schwester - Marcjanna (1926-2003).

Im vorliegenden Artikel wurde die Familie des Seligen in einigen bewusst gewählten Dimensionen allgemein geschildert. Die Darstellung betrifft ihren Personenbestand, berufliche und soziale Tätigkeit ihrer Mitglieder, nähere Vorstellung des Familienhauses in Chełmża, Beschreibung einiger schwerer Momente im Familienleben, sowie detaillierte Schilderung der Elternpersönlichkeiten.

Die tiefe Familienerfahrung, welche die Person des sel. P. Stefan ausstrahlt, überträgt sich auf ein interessantes Phänomen: in den Bitten und Danksagungen, die auf die Fürsprache des sel. gerichtet werden, stößt man auf viele familienbezogene Gebete. Sie sprechen verschiedenartige Freuden, Kümmernisse und Sorgen an, jedoch im Mittelpunkt steht das Wort „Familie”.

${ }^{27}$ J. Durczewski, Idea braterstwa harcerskq stużba, Biuletyn Parafii Wniebowzięcia Najświętszej Marii Panny i Błogosławionego Księdza Stefana Wincentego Frelichowskiego w Toruniu, nr 8 (Błogosławiony Ksiądz Stefan Wincenty Frelichowski, Materiały, nr 8), Toruń 2004, s. 35.

${ }^{28}$ Część z nich została opublikowana w kilku numerach Biuletynu Parafii Wniebowzięcia Najświętszej Marii Panny i Błogosławionego Księdza Stefana Wincentego Frelichowskiego w Toruniu, większość rękopisów znajduje się w archiwum parafii NMP w Toruniu. 